\title{
Negative Elongation Factor C/D
}

National Cancer Institute

\section{Source}

National Cancer Institute. Negative Elongation Factor CID. NCI Thesaurus. Code C105099.

Neg ative elong ation factor C/D (590 aa, $\sim 66 \mathrm{kDa}$ ) is encoded by the human NELFCD gene. This protein is involved in transcriptional pausing. 